\title{
Article
}

\section{Emergence of 3D Printed Dosage Forms: Opportunities and Challenges}

\author{
Albed Alhnan, Mohamed, Okwuosa, Tochukwu Chijioke, Sadia, \\ Muzna, Wan, Ka-Wai, Ahmed, Waqar and Arafat, Basel \\ Available at http://clok.uclan.ac.uk/14992/ \\ Albed Alhnan, Mohamed, Okwuosa, Tochukwu Chijioke, Sadia, Muzna, Wan, \\ Ka-Wai, Ahmed, Waqar ORCID: 0000-0003-4152-5172 and Arafat, Basel (2016) \\ Emergence of 3D Printed Dosage Forms: Opportunities and Challenges. \\ Pharmaceutical Research, 33 (8). pp. 1817-1832. ISSN 0724-8741
}

It is advisable to refer to the publisher's version if you intend to cite from the work. http://dx.doi.org/10.1007/s11095-016-1933-1

For more information about UCLan's research in this area go to http://www.uclan.ac.uk/researchgroups/ and search for <name of research Group>.

For information about Research generally at UCLan please go to http://www.uclan.ac.uk/research/

All outputs in CLoK are protected by Intellectual Property Rights law, including Copyright law. Copyright, IPR and Moral Rights for the works on this site are retained by the individual authors and/or other copyright owners. Terms and conditions for use of this material are defined in the policies page.

\section{CLoK}

Central Lancashire online Knowledge www.clok.uclan.ac.uk

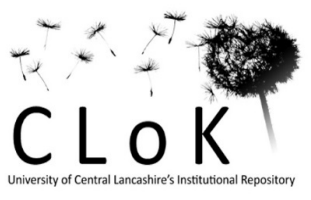


EXPERT REVIEW

\section{Emergence of 3D Printed Dosage Forms: Opportunities and Challenges}

Mohamed A Alhnan ${ }^{1 *}$, Tochukwu C Okwuosa ${ }^{1}$, Muzna Sadia ${ }^{1}$, Ka-Wai Wan ${ }^{1}$, Waqar Ahmed ${ }^{2}$, Basel Arafat $^{1}$

${ }^{1}$ School of Pharmacy and Biomedical Sciences, University of Central Lancashire, Preston, Lancashire, UK

${ }^{2}$ School of Medicine, University of Central Lancashire, Preston, Lancashire, UK

*Corresponding author:

Mohamed A Alhnan

School of Pharmacy and Biomedical Sciences

University of Central Lancashire

Preston PR1 2HE

United Kingdom

T: +44 (0)1772 893590

E: MAlbedAlhnan@uclan.ac.uk 


\section{ABSTRACT}

The recent introduction of the first FDA approved 3D-printed drug has fuelled interest in 3D printing technology, which is set to revolutionize healthcare. Since its initial use, this rapid prototyping (RP) technology has evolved to such as extent that it is currently being used in a wide range of applications including in tissue engineering, dentistry, construction, automotive and aerospace. However, in the pharmaceutical industry this technology is still in its infancy and its potential yet to be fully explored. This paper presents various 3D printing technologies such as stereolithographic, powder based, selective laser sintering, fused deposition modelling and semi-solid extrusion 3D printing. It also provides a comprehensive review of previous attempts at using 3D printing technologies on the manufacturing dosage forms with a particular focus on oral tablets. Their advantages particularly with adaptability in the pharmaceutical field have been highlighted, including design flexibility and control and manufacture which enables the preparation of dosage forms with complex designs and geometries, multiple actives and tailored release profiles. An insight into the technical challenges facing the different $3 \mathrm{D}$ printing technologies such as the formulation and processing parameters is provided. Light is also shed on the different regulatory challenges that need to be overcome for 3D printing to fulfil its real potential in the pharmaceutical industry.

KEY WORDS additive manufacturing, rapid prototyping, three-dimensional, FDM, FFF, Patientspecific 


\section{ABBREVIATIONS}

3D Three-dimensional

APIs Active pharmaceutical ingredients

CLIP Continuous layer interface production

EXT Semi-solid extrusion

FDM Fused deposition modelling

FFF Fused Filament Fabrication

HPC Hydroxypropyl cellulose

HPMC Hydroxypropylmethyl cellulose

PB Powder based

PCL Polycaprolactone

PEG Polyethylene glycol

PLLA Poly (-L) lactic acid

PVA Poly vinyl alcohol

PVP Polyvinylpyrrolidone

SLA Stereolithographic

SLS Selective laser sintering 


\section{INTRODUCTION}

The demand for a unique approach for individualized medicine is rising rapidly. There is now greater emphasis on a patient-specific or tailored method of dosing and dose combinations instead of the standard mass produced medicines based on "One Size Fits All" (1). The need to individualized dosing arises from differences in the patient's age, weight and severity of disease. These conditions require the modification of a dose that is suited the patient's individual needs thus minimising potential for adverse effects of the drug. It was reported that $75-85 \%$ of adverse effects from drug therapy occur as a result of inappropriate dosing or dose combinations (2).

Despite advancements in drug administration methods the oral route of administration is still the most preferred choice by patients. This preference stems up from the fact that they are relatively safe, very convenient, easy to use and affordable. Approximately $40 \%$ of drug delivery are taken through the oral route (3). Oral drug delivery market values is expected to rise from $\$ 49$ billion in 2010 to $\$ 97$ billion by 2017 (4). Since the use of oral solid dosage forms (especially tablets) have earned widespread acceptance by most patients and carers, personalisation of dosage form is a potential breakthrough in the healthcare system.

A major implication of personalized medicine is the urgent necessity to modify drug dosing and drug combinations and customized healthcare to meet an individual patient's need. Therefore, methods for tailoring the dosage forms to individual patient's needs are highly desirable. The conventional manufacturing processes involved in the production of popular oral solid dosage forms (e.g. tablets and capsules) have been designed for large-scale manufacturing. They lack flexibility in dosing, particularly when dose variations or drug combinations are involved. In addition, major capital is needed to acquire several equipment, large operation spaces and demands highly skilled operators to function efficiently and safely. The employment of several steps (milling, mixing, granulation, drying etc.) involved in manufacturing processes (5) renders the process too rigid for high level of flexibility required to bring personalized medicines into reality.

Dose modifications for solid dosage forms are currently achieved through the dispensing of multiple low dose tablets to obtain a higher dose or by splitting/dividing larger sized tablets. It is estimated that 3000 compounding pharmacies fill more than 30 million prescriptions per year in the United States in an attempt to customize drugs for individual patients (6). Tablet division is achieved mainly using hands, 
knives or tablet splitters, which introduce dose variations due to uneven weight distribution after splitting (7-12). Splitting solid dosage forms could also impact on release kinetics, especially for controlled or extended release formulations $(13,14)$. Moreover, fractioning of tablets can directly affect the integrity of the coating system leading to premature drug release. Splitting tablets might also be challenging for the elderly or patients with certain disease conditions e.g. arthritis.

\section{APPROACHES TO PERSONALIZED MEDICINES}

\section{LIQUID DOSAGE FORMS}

In order to improve drugs' efficiency and minimize their adverse effects, several approaches have been adopted in dose personalisation. For decades, the use of liquid dosage forms has been employed in personalising the dose. This can be easily achieved by altering the volumes administered using various dosing aids, usually by including a dispenser as a part of the packaging (15). This is the dosage form of choice for infants, toddlers and children due to the ease of modifying the dose in addition to overcoming swallowing difficulties with solid dosage forms. Liquids may also be used by adults especially in geriatrics with swallowing difficulties (16). Where no suitable licensed liquid dosage forms are available, prescribers may need to order these from Specials Manufacturers to meet the need of these patients (17).

Despite the advantages of liquid dosage forms, they lack efficiency especially when large doses are required. Some drugs cannot be manufactured as liquids due to poor solubility of many actives. Their preparation in the form of suspensions could bring about physical chemical and microbiological stability challenges particularly during storage. Drugs in their solid state also normally have a longer half-life (18), making liquids less suitable for long term storage since liquids support the growth of microorganisms. Inaccuracies in dosing could result from irregularities in the measurements from the dosing aids $(19,20)$ or from the patient or carers incompetence $(21)$. In addition, manufacturing liquid dosage forms is capital-intensive and products are usually significantly heavier which increase the delivery and storage costs.

\section{INKJET PRINTING}


Another approach to personalized medication involves the use of inkjet printers. This idea originated from the same technique used in computer-operated inkjet printing which recreates digital images by propelling ink droplets onto paper. It was adapted for pharmaceutical application by the replacement of the ink with pharmaceutical solutions containing drugs and normal paper with edible sheets known as substrates $(22,23)$. A list of the possible substrates that could be used in ink jet printing has be compiled in a review by Alomari et al., (2014)(24). Manipulating the dose in inkjet printing could be achieved by changing the number of printed layers for a given area or by increasing the total printed area. The advancements in inkjet printing were based on the potential to print designed ratios of drugs and excipients as individual microdots onto an edible substrate. Two main inkjet dispensing systems have been investigated for pharmaceutical applications: thermal $(23,25)$ or piezoelectric inkjet printers $(26$ 29).

Inkjet drug printing offers a significant advantage of accurate control of dose combination and pattern of drug release. It has demonstrated that deviations as low as $1.4 \%$ relative standard deviation can be achieved when $1 \mathrm{~cm}^{2}$ is printed with about $52 \mu \mathrm{g}$ of the model drug (1). This however, is influenced by the nature of the substrate or printing technology $(25,30)$.

Ink jet printing requires the starting materials to possess certain characteristics mainly; particle size needs to be $<1 \mu \mathrm{m}$ to avoid clogging the printer head, viscosity needs to be $<20 \mathrm{cP}$ and surface tension between $30-70 \mathrm{mN} / \mathrm{m}$ for efficient flow $(27,30)$. Ink jet printing is thus highly suitable for manufacturing drugs with low therapeutic doses, ideally in the microgram range, since they require a smaller area on the substrate. Obtaining higher doses will otherwise imply numerous printings on a particular area, which could lead to longer drying time and potential instabilities. A large surface area could be covered for larger doses but this means that a greater amount of substrate needs to be consumed thus inflating the size of the dosage form.

\section{D PRINTING TECHNOLOGIES}

3D printing or additive manufacturing is a highly attractive technology that produces 3 -dimensional objects by constructing successive layers of the used material under the control of computer software. Its ability to produce complex shapes and geometries remains one of its major advantages in manufacturing. It has established roots in engineering and many non-medical practices, especially in the automobile industries. Recently its applications in medical devices $(31,32)$, implants (33), tissue 
regeneration $(34,35)$ and pharmaceutical dosage forms $(36-38)$ etc. have been demonstrated with a wave of excitement particularly with regards to its potential in personalized medicine.

Several technologies have been employed in the construction and stacking of layers of 3D printed objects. Table I summarises the principle mechanisms employed by the most common 3D printing technologies. The name of the technology is usually related to the technique involved in layer formation. $3 \mathrm{D}$ printing in its essence is repeated and co-ordinated two-dimensional printing. The main focus in this review is on multi-layer 3D printing whilst single layer printing of flat object is considered less relevant.

\section{a. Stereolithographic 3D printing (SLA)}

Stereolithographic 3D printing involves the curing of photo-sensitive material/s (photo-polymerization) to produce a 3D object (39). Support structures may be designed to connect the different parts of the object in all phases of the building, thus, avoid the collapsing of the object during printing. Curing of the polymers is usually performed using ultraviolet (UV) light $(40,41)$ or the use of a digital light projection technique (DLP). SLA employs a digital mirroring device (42-44) to initiates a chemical reaction in the photopolymer which causes the gelation of the exposed area. This process is repeated layer after layer to build the entire parts of the object (Fig. 1a). This occurs as unreacted functional groups on the solidified structure in the first layer polymerises with the illuminated resin in the next layer ensuring adhesion and therefore, layer formation (45). Post printing processing is usually required to further cure the final product, to improve its mechanical integrity and to polish or remove the attached supports to the fabricated object (39).

The liquid photopolymer resins employed in SLA are usually low-molecular weight polyacrylate, epoxy macromers or monomers which form very rigid, glassy and brittle materials $(39,46)$. The technology is efficient when it comes to rapid prototyping, with high level of accuracy and resolution. It can build objects that measures several cubic centimetres with a resolution down to $0.2 \mu \mathrm{m}$ (47). Even though it is widely used in tissue engineering $(41,44,48)$ and the fabrication of implantable devices $(49)$ very few studies have been carried out in pharmaceutical applications.

This technique has several disadvantages such as the potential health hazards from the use of resins as they are potential carcinogens. These resins are also photosensitive therefore long-term stability is problematic. In addition, SLA 3D printing technique is time consuming with a printing speed of about 1- 
$3 \mathrm{~cm} /$ hour (50). However, a recent advancement in this technology has made it possible to achieve speeds up to $100 \mathrm{~cm} /$ hour in a process that fabricates the 3D object in a non-layer by layer fashion (51). This is known as continuous layer interface production (CLIP) where the creation of a dead zone (i.e. oxygen-containing zone that ensures photo-polymerization) could increase the printing speed

\section{b. Powder based (PB) 3D printing}

PB 3D printing technology was developed by the Massachusetts Institute of Technology (MIT) in the 1980s (52). It involves the distribution of thin layers of powder (via powder bed or powder jetting mechanisms) selectively joined by applying drops of liquid binder from an inkjet or piezoelectric printer head (36). In alternative methods, binder solutions are jetted onto the powder layers (53) (Fig. 1b). PB 3D printing has expanded into areas such as tissue engineering and pharmaceutical applications over a decade between 1993 to 2003 leading to its use in the manufacturing of implants (54) and oral dosage forms $(36,55)$.

The use of PB 3D printing has been investigated for the fabrication of delayed release of drugs (56), with complex release profiles such as immediate-extended or dual pulsatory (57) as well as zero order release (58-60). For example, Pryce-Lewis et al. (2003) developed cylindrical drug delivery systems exhibiting zero-order release profiles using a method that involved uniaxial compression of PB 3D printed tablets (58). Yu et al. (2007) employed the method to construct a methacrylic or ethylcellulose matrix tablet to achieve a linear release of diclofenac sodium (59). The ability to construct complex formulation designs, even ones with loose powders in its inner regions, was also demonstrated using PB 3D printing $(37,61)$. A PB 3D printed core-shell structure containing the drug pseudoephedrine hydrochloride was also constructed and drug release was shown to be nearly at zero order (60).

Recently, this technique has also been used in the fabrication of fast disintegrating tablets (61). A pioneering example of the commercialisation of powder based technology is the development of ZipDose $^{\circledR}$, the first FDA approved 3D printed tablet. This dosage form comprises of a highly porous structure even, at high doses (up to $1000 \mathrm{mg}$ ) which facilitates its rapid dispersion on contact with liquid (52). 
The starting materials (i.e. powders and binder solutions) are already widely used in the pharmaceutical industry thus enabling the adaptation of PB 3D printing into manufacturing in compared to other $3 \mathrm{D}$ printing technologies. Nevertheless, PB 3D printed constructs usually require additional drying steps to eradicate residual solvents and improve physical resistance. Post-printing processes must also be carried out to remove excess powders accumulated during printing, confining its use to specialized powder laboratories and implicate significant wastage. The high porosity of structures resulting from PB $3 \mathrm{D}$ printing is associated with poor mechanical resistance and high friability $(36,61)$. Furthermore, since PB 3D printing is limited by the thickness of the powder layer, achieving high resolution objects can be challenging (45).

\section{c. Selective laser sintering (SLS) 3D printing}

SLS 3D printing is similar to powder based 3D printing except in this technology laser radiations are used to liquefy (fully or partially) and fuse the layered powders (62) (Fig. 1c). This is a standard technique for 3D printing of metals (63-69). The powders or starting materials that could be used include; polyamides, polystyrenes or polycarbonates (70). The sintered materials form part of the final object while the un-sintered materials remain as part of the supporting structure and requires post printing processing to be removed (71).

The use of SLS in tissue engineering is well established $(72,73)$ and has been also applied effectively in several other non-medical manufacturing industries $(74,75)$. Thus far, it has not been used in pharmaceutical applications possibly due to the high energy input from the laser beam raising concerns about the possibility of drug and pharmaceutical excipients' degradation.

\section{d. Fused deposition modelling (FDM) 3D printing}

FDM, also known as Fused Filament Fabrication (FFF) and first commercialized in 1991 (70) is currently one of the most commonly used low-cost techniques in 3D printing. In FDM, the object is formed by layers of melted or softened thermoplastic filament extruded from the printer's head at specific directions as dictated by computer software. Inside the FDM's head the material is heated to just above its melting point which is then extruded through a nozzle, and deposited layer by layer, solidifying in under a second 
(45) (Fig. 1d). The application of this technology has been established for non-pharmaceutical purposes with a wide range of low cost printers available (76).

Recently, FDM 3D printing has found its way into drug research and development where thermoplastic polymers such as PVA have been utilized as drug carriers. Initially drug loading into commercially available PVA filaments was achieved by incubation in saturated drug organic solutions. Goyanes et al. (2014) studied the incorporation of fluorescein into commercially available PVA filaments and the release of the dye was controlled using different infill percentages (77). Skowyra et al. (2014) demonstrated the capability of FDM in printing PVA filaments exhibiting an extended drug release of prednisolone for up to $24 \mathrm{~h}$ following oral administration (78). The potential of FDM in achieving extended release was also shown for 5-aminosalicylic acid (5-ASA) or 4-aminosalicylic acid (4-ASA). Moreover, the production of tablets with different geometries; pyramid, cube, cylinder, sphere and torus was proven to be viable using FDM 3D printing (79). Nevertheless, a major limitation for the use of FDM is the elevated temperature required for its operation $\left(\sim 220^{\circ} \mathrm{C}\right)$, which may degrade a significant number of pharmaceutical excipient and active drugs (38).

Drug loading in the filament is usually achieved through incubation in organic solvents and poor drug loading may limit its use to low dosed drugs $(38,77,78)$. Until recently, FDM was confined to using nonpharmaceutical grades of PLA and PVA. These polymers, however, have been used to achieve mainly extended release preparations. Nevertheless, recently, Pietrzak et al. (2015) bridged FDM 3D printing with hot melt extrusion (HME) in an attempt to increase the range of polymers that can be adapted with FDM and achieve higher drug loading. They demonstrated the feasibility of printing immediate and extended theophylline caplets based on cellulosic or methacrylic polymeric filaments with $50 \%$ drug loading (80).

\section{e. Semi-solid extrusion (EXT) 3D printing}

Another method of 3D printing involves layer-by-layer deposition of semi-solids (starting materials) through a syringe based tool-head (Fig. 1e). Semi-solids (gels or pastes) are formulated by mixing optimal ratios of polymers and appropriate solvent(s) in order to obtain a viscosity suitable for printing 
$(81,82)$. It has a wide range of applications and the availability of bench top platforms further encourages its creative use in rapid prototyping of numerous objects.

Khaled et al. (2014) pioneered manufacturing guaifenesin bilayer tablets using EXT and compared them to their commercially available counter parts (81). Similar release profile of 3D printed tablets and branded tablets demonstrated the versatility of EXT 3D printing in addition to offering an easier approach to drug manufacturing. The technique has also been used in multi-active tablets capable of delivering three drugs via two different release mechanisms; osmotic release and diffusion through the shell and gel layers, respectively (83). Furthermore, Khaled et al. (2015) demonstrated the feasibility of EXT 3D printing in constructing a multi-compartment polypill containing five actives and exhibiting a well-defined and independently controlled; immediate or sustained release profiles (84).

Although 3D printing by extrusion does not require high temperature; extrusion requires materials to be in the form of gels or pastes which implies that shrinking or deformation of the product may occur following the drying process. The fabricated object may also collapse during 3D printing if a constructed layer did not harden sufficiently to withstand the weight of the successive layers. The technique is usually confined to a low resolution due to the fact that an orifice with a size of $0.4-0.8 \mathrm{~mm}$ is typically employed in EXT 3D printing. Table II highlights previous studies conducted in the field of drug delivery employing 3D printing technologies. 


\section{WHAT 3D PRINTING CAN BRING TO TABLET MANUFACTURING?}

$3 \mathrm{D}$ printing has been evolving rapidly and the emergence of its various types is challenging the traditional ways that many products are produced. Its versatility, speed, cost and potential for tailored manufacturing is set disrupt many of the traditional manufacturing technologies. In this review the therapeutic and potential technical benefits of 3D printing to established tablet manufacturing industry are explored:

\section{a. Tailored dose}

$3 \mathrm{D}$ printing is highly flexible and it is relatively simple to change the shape and size of the dosage form in response to patient or clinicians' needs compared to traditional manufacturing techniques. Such ability has been exploited to modify the dose by manipulating the scale of the printed tablet via software order $(78,80)$. This is particularly important for paediatric doses where wide range of doses are frequently requested. Such flexibly enables the shape of the tablet $(85,86)$ to be made to suit a particular patient with swallowing difficulties.

3D printing can also be extended to produce multiple active ingredient dosage forms, either as a single blend or as multi-layer or reservoir printed tablets to reduce the frequency and number of tablets taken by the patients daily (83). Various studies elucidated the flexibility of these technologies in fabricating bilayer tablets e.g. chlorpheniramine maleate and diclofenac (55) acetaminophen and caffeine (86) or even multiactive tablets e.g. captopril, nifedipine and glipizide which has the potential to treat hypertensive diabetic patients (83). The therapeutic efficiency of combination therapy is wellestablished in cardiovascular protection and a number of fixed-dose combination therapies have been developed. The polypill concept has attracted considerable interest due to its proven efficiency in the treatment and prevention of cardiovascular disease and high blood pressure (87-89). However, the restricted dose-combination overlook the changing needs of an individual patient, which is important for this concept to fulfil its potential. Khaled et al. (2015) demonstrated the feasibility of extrusion based 3D printing for the fabrication of a polypill containing the drugs hydrochlothiazide, ramipril, aspirin, pravastatin and atenolol (84). Hence, highlighting the potential of 3D printing technologies in the individualised 'polypill' concept. 
b. Mini-dispenser unit

3D printers require minimal space (e.g. FDM or SLA) allowing them to fit in any environment, are affordable and can be remotely controlled using computer software and network (90). Moreover, 3D printing technologies allows not only small batches but individual items to be fabricated within a single manufacturing run. These characteristics allows 3D printer to function as a mini-dispenser to potentially bring tablet manufacturing closer to patients. For this to be achieved, stable and reproducible starting material needs to be mass-produced. This will delay the last step in tablet manufacturing and bring it closer to the patient (Fig. 2) (81). Fig. 3 summarise the composition of the proposed starting materials that can be used in all of these technologies.

c. Integrated with healthcare network

3D printers are computerized fabricator that can produce complex 3D objects using data generated by computer software opens the door for a more dynamic supply chain. Developments in sensor technology will enable sensors to be implanted in or worn by patients to generate an inline clinical data feed which can be transmitted to and stored by healthcare staff (90). Physicians and pharmacists will be able to modify the next dose or drug combinations according to patient's changing needs reflected by the transmitted data. As 3D printers can be remotely controlled, 3D printing of a dose will take place in the most accessible location to the patients (Fig. 4). Hence, such a dispensing system offers a clear advantage of shortening the time of a clinical response to patient's needs and improving patient's compliance by offering a seamless experience.

\section{d. New geometries and designs.}

The capacity of $3 \mathrm{D}$ printing in accurately constructing dosage forms with low content of active ingredients, as low as $10^{-12}$ mole per tablet has been demonstrated (36). Unlike conventional powder compression tableting technologies accurate spatial distribution of ingredients within a dosage form can also be achieved, hence opening a window to a large number of design and complex geometries not possible with traditional manufacturing methods. For instance, hollow or partly filled tablet designs which were not possible using conventional compression techniques can be readily made using 3D printing (77). 3D printing technologies also have the capability of positioning the active material in the fabricated 
object at will (90). Fig. 5 highlights a variety of tablet designs fabricated by different 3D printing technologies.

The creation of medications with complex drug-release profiles is one of the most researched uses of 3D printing (91). For example, different shapes and geometries of dosage form can be also used to achieve different release profiles. Rowe et al. (2000) fabricated tablets with complex release profiles using 3D printing including; immediate-extended, breakdown, enteric dual pulsatory and dual pulsatory (55). Sun and Soh (2015) controlled the release profile of a dye contained in a surface-eroding polymer by fabricating different shapes of the polymer. The modifications of matrix shape resulted in constant, pulsed, increasing or decreasing dye release profiles (57). Goyanes et al. (2015b) used the FDM process to create complex geometries and showed that, according to the shape of the drug delivery system, it was possible to control the drug dissolution profile (77).

\section{e. Accelerated disintegration}

One significant difference in 3D printing compared to powder compression is the pattern of powder aggregation within the tablet structure. In some examples of PB 3D printing, powder binding was confined to the periphery of the tablet design leaving a 'loose' powder in the centre $(37,61)$. Such a design proved to be instrumental in development of faster disintegrating tablets. Aprecia's ZipDose ${ }^{\circledR}$ demonstrated the capability in disintegrating in less than 10 seconds whilst containing a high dose of piracetam (1000 mg) (52).

\section{LIMITATIONS OF 3D PRINTING}

Although 3D printing is highly promising for manufacturing personalized dosage form, there are several technical and regulatory challenges need to be overcome before it is widely used for pharmaceutical applications

Several 3D printing technologies (EXT, FDM and PB) rely on nozzle mechanism to build sequenced layers during the formation of the printed object. This creates a major challenge of maintaining a reproducible and consistent flow on demand as the print head stops and re-starts during printing a single or multiple objects. In powder based 3D printing for example, clogging of the nozzles in the 3D 
printer head, binder migration and bleeding and improper powder feeding and scraping are problems that need to be addressed (90). Powder based 3D printing in particular requires special laboratories to conduct the printing in since removal of excess powder which potential health and occupational hazards may be necessary (93).

Another limitation of 3D printing is appearance of the finished product, where surface imperfections may be visible due to stacking of plastic beads or large-sized powder on top of each other (94). This is of particular significance in powder based and extrusion based 3D printing since significant drying time is required before it is possible to handle. Furthermore, post-treatment processes such as drying duration, rate and method can affect the properties and appearance of the final product. This is of significant importance in powder based, inkjet and extrusion-based 3D printing which all require post-operative drying (95). Seam lines between layers also tend to occur, when FDM 3D printing is in use (96). Nevertheless, Pietrzak et al. (2014) showed improved tablet morphology when methacrylic polymers were employed in 3D printing of drugs particularly when a high resolution (100 um layer thickness) was employed (80).

The mechanical resistance of 3D printed tablets is dependent on its production technology. While FDM tends to produce highly resistant tablets (80), powder based and EXT 3D printing yields weaker structures. This was exhibited in their higher friability values (3.55\%) (37) compared to conventional tablets $(81,97)$. However, significant improvement have been achieved through a more resistant shell structure in a shell-core tablet design (37).

Thus far, the material choices, colours, and surface finishes currently available for 3D printing are relatively limited when compared to conventional tablet compression processes. In the case of SLA 3D printing, the materials are confined to photopolarizable oligomers (56). In the case of FDM, it is impulsive to include thermoplastic polymers to fabricate the object through extrusion from a hot nozzle (90). Table III provides a balance sheet of major advantages and limitations of the different 3D printing technologies. 


\section{REGULATORY CHALLENGES}

3D printing technologies advancements have brought the prospect of personalized dose a step closer. However, can regulatory bodies and current legal framework handle the ambiguity of this boldly marching technology?

The distinction between compounded and manufactured medicine is a central question about the regulations of 3D printed medicine. This question has major implications on the level of regulation for the 3D printed products. Tragic incidents such as, the New England Compounding Centre (NECC) in 2012 (98) and dozens of other dangerous safety problems at compounding pharmacies $(99,100)$, have put the safety of pharmaceuticals under the spotlight. Moreover, important issues concerning 3D printed medicines like tort liability and intellectual rights needs to be addressed to protect manufacturers and end users.

$3 \mathrm{D}$ printing and its potential in reshaping pharmaceutical product development and manufacturing have not escaped the attention of regulatory bodies. However, meeting current regulatory requirements of the FDA may be a significant hurdle that may impede their introduction to the market (101). Several questions need to be answered in this regard: Which regulatory pathway will the innovators take to approach such non-traditional devices? Will the regulatory process comprise the 'pharmaceutical ink', and $3 \mathrm{D}$ printer as well as the end product? For those issues to be resolved, FDA may need to issue a short term guidance documents and look into modifying its traditional regulations to follow up with this rapidly-evolving technology (102).

FDA recognized that new issues implicating this technology will arise and the process for change is already underway. It is working on developing a sound understanding of 3D printing through its own research (103). In particular, two laboratories within the FDA's Office of Science and Engineering Laboratories (OSEL), the Laboratory for Solid Mechanics and FDA's Functional Performance and Device Use Laboratory are being utilized for the purpose of studying the potential effects of 3D printing (104). In controversy, despite the rapidly building momentum of 3D printing, FDA's planned guidance on 3D printing fell to the "B-list" in its 2015 medical device guidance agenda (105). Hence, a clear regulatory pathway regarding 3D printed products is likely to take some time (106). 
More lessons regarding approval of 3D printed products can be explained from medical devices, approximately eighty five 3D printed medical devices and implantables have gained FDA clearance (101). Several pathways exist to obtain FDA approval, amongst which are the 510 (k), PMA, de novo, HDE, etc. To date, all approved medical devices and implantables generated using this technology were granted clearance through the Premarket Notification - also called PMN or 510 (k) pathway (107) by proving that "3D printed product is substantially equivalent to a legally marketed device" (108). Such a regulatory approach can also be implemented for dosage forms by approving a 3D printed dosage form as a bioequivalent product to approved ones.

Beside the traditional clearance routes, the FDA may also provide approval of 3D medical devices through abbreviated pathways. These pathways include emergency use pathways, compassionate use exemption pathways. In 2013 for example, a new born's life suffering from tracheobronchomalacia was at risk, and via the emergency-use exemption pathway, an anatomically specific tracheal splint was approved to save the baby's life (109). However, whether or not 3D printing of dosage forms could pass through these abbreviated routes is not clear.

In spite of all regulatory hurdles associated with 3D printing medicine, the FDA approved the first 3D printed pill, Spritam ${ }^{\circledR}$ (levetiracetam) in August 2015. In this case the product is considered as approving mass-produced new production for equivalent product (52). 


\section{CONCLUSIONS}

The rapidly evolving 3D printing technologies and the dawn of pharmaceutical inks have huge potential in dosage form personalisation required by patients. This will revolutionize compounding dosage forms and bringing dosage form manufacturing closer to end users providing more relevant, effective and safe dose to the patient.

Several 3D printing technologies have been employed to fabricate solid dosage forms for oral drug delivery. PB 3D printing technologies have evolved with several patent applications and an FDA approved product to be introduced to the market. FDM and EXT systems have also emerged in the last two years illustrating a highly promising potential for personalized dose.

Despite making massive inroads into other manufacturing industries such as aerospace and automobile pharmaceutical 3D printing is still at its infancy. Many technical and regulatory challenges need to be overcome before widespread adoption in the pharmaceutical industry. However, the pace at which 3D printing is currently developing and the advantages that it brings to personalized dosage form, its importance cannot be ignored.

\section{ACKNOWLEDGMENTS AND DISCLOSURES}

The authors would like to thank UCLAN Innovation Team for this support and Mrs Reem Arafat for her help with graphics design.

Conflicts of interest: M A Alhnan is the innovator in pending UK patent applications P218530GB1 and P227819GB in the field of 3D printing of medicines. 


\section{List of Tablets}

Table I Concept and minimum layer thickness of main stream 3D printing technologies.

Table II Summary of literature examples of 3D printed dosage form, intended aim, used active pharmaceutical ingredients (APIs) and excipients.

Table III Summary of advantages and limitations of 3D printing technologies.

\section{List of Figures}

Fig. 1 Mechanism of various 3D printing technologies: (a) Stereolithographic (SLA), (b1-2) Powder bed and powder jetting, (c) Selective laser sintering (SLS), (d) Semi-solid extrusion (EXT) and (e) Fused deposition modelling (FDM).

Fig. 2 Schematic diagram of different steps involved in tablet manufacturing. 3D printing can delay the last manufacturing step and bring it closer to patients.

Fig. 3 Examples of starting material for 3D printing and their corresponding 3D printed products: (a) Oligomer solution and (a1) a scaffold printed using SLA (44) (b) Powder + binder solution and (b1) a tablet printed using PB (61), (c) Powdered polymer and (c1) a scaffold printed using SLS (73), (d) Filament and (d1) an extended release tablet printed using FDM (78), (e) Polymer solution + powder (semi-solid) and (e1) a controlled release bilayer tablet printed using EXT (81). (Awaiting permission).

Fig. 4 Integration of 3D printing technologies within a proposed patient-centred healthcare system. Inline clinical data generated from sensors in patient's body feed into healthcare network. Healthcare staff can access the data and order an e-prescription of an individualised dosage form in response to patient's data. A 3D printer can locally fabricate the dose for the patient, hence providing an enhanced and seamless patient experience.

Fig. 5 Examples of different designs used to manufacture 3D printed tablets. Simplistic design of disc has been initially employed (a) (77). Oval shape (b) (78) and an easier to swallow caplet shape was possible to fabricate using FDM 3D printing (C) (80). FDM 3D printing allowed fabrication of partially hollow tablets (d) (77). PB 3D printing constructed shell-core structure by selective deposition of binder solution in the shell domains (e) (36) and by adding internal supporting walls, tablet's physical resistance can be improved (f) (61). PB 3D printing was also utilized to build doughnut shape tablets with linear drug release (g) (85). Pulsated drug release (h) and accelerating drug release (i) were achieved using casted gels in 3D printed containers (57). Multi-layer (j) and core-shell (k) caplets allowed simultaneous and sub sequential release of two actives (86). Polypills of 3 drugs (I) (83) or 5 different drugs (m) (84) with immediate and extended release patterns were EXT 3D printed. 


\section{References}

1. Raijada D, Genina N, Fors D, Wisaeus E, Peltonen J, Rantanen J, Sandler N. A step toward development of printable dosage forms for poorly soluble drugs. Journal of pharmaceutical sciences. 2013;102(10):3694-3704.

2. Cohen JS. Ways to minimize adverse drug reactions. Individualized doses and common sense are key. Postgrad Med. 1999;106(3):163.

3. Marketsandmarkets. Drug delivery technology market. 15/10/2015. Available from: http://www.marketsandmarkets.com/Market-Reports/drug-delivery-technologies-market1085.html?gclid=CIXRuMT5osQCFe6WtAodmiUAZg.

4. GBIResearch. Oral drug delivery market report. 16/11/2015. Available from: http://www.contractpharma.com/issues/2012-06/view features/oral-drug-delivery-marketreport/.

5. Ervasti T, Simonaho SP, Ketolainen J, Forsberg P, Fransson M, Wikstrom H, Folestad S, Lakio $\mathrm{S}$, Tajarobi P, Alami SA. Continuous manufacturing of extended release tablets via powder mixing and direct compression. Int J Pharm. 2015;495(1):290-301.

6. College WCM. Study Shows Inconsistent dosages of widely used eye disease drug. 10/12/2015. Available from: http://weill.cornell.edu/news/pr/2014/09/study-showsinconsistent-dosages-of-widely-used-eye-disease-drug-szilard-kiss-donald-damico.html.

7. Habib WA, Alanizi AS, Abdelhamid MM, Alanizi FK. Accuracy of tablet splitting: Comparison study between hand splitting and tablet cutter. Saudi Pharm J. 2014;22(5):454-459.

8. Helmy SA. Tablet splitting: is it worthwhile? Analysis of drug content and weight uniformity for half tablets of 16 commonly used medications in the outpatient setting. J Manag Care Spec Pharm. 2015;21(1):76-86.

9. Hill SW, Varker AS, Karlage K, Myrdal PB. Analysis of drug content and weight uniformity for half-tablets of 6 commonly split medications. J Manag Care Pharm. 2009;15(3):253-261.

10. Tahaineh LM, Gharaibeh SF. Tablet splitting and weight uniformity of half-tablets of 4 medications in pharmacy practice. J Pharm Pract. 2012;25(4):471-476.

11. Pouplin T, Phuong PN, Toi PV, Nguyen Pouplin J, Farrar J. Isoniazid, pyrazinamide and rifampicin content variation in split fixed-dose combination tablets. PLoS One. 2014;9(7):e102047.

12. van Riet-Nales DA, Doeve ME, Nicia AE, Teerenstra S, Notenboom K, Hekster YA, van den Bemt BJ. The accuracy, precision and sustainability of different techniques for tablet subdivision: breaking by hand and the use of tablet splitters or a kitchen knife. Int J Pharm. 2014;466(1-2):44-51.

13. Erramouspe J, Jarvi EJ. Effect on dissolution from halving methylphenidate extended-release tablets. The Annals of pharmacotherapy. 1997;31(10):1123-1126.

14. Shah VP, Yamamoto LA, Schuirman D, Elkins J, Skelly JP. Analysis of in vitro dissolution of whole vs. half controlled-release theophylline tablets. Pharmaceutical research. 1987;4(5):416-419.

15. Brown D, Ford JL, Nunn AJ, Rowe PH. An assessment of dose-uniformity of samples delivered from paediatric oral droppers. J Clin Pharm Ther. 2004;29(6):521-529.

16. Rosemond. Medicine management for patients with trouble swallowing pills. 12/3/2015. Available from: http://www.rosemontpharma.com/health-professionals.

17. Schiele JT, Quinzler R, Klimm HD, Pruszydlo MG, Haefeli WE. Difficulties swallowing solid oral dosage forms in a general practice population: prevalence, causes, and relationship to dosage forms. Eur J Clin Pharmacol. 2013;69(4):937-948.

18. Pamudji JS, Mauludin R, Nurhabibah. Influence of $\beta$-cyclodextrin on Cefixime Stability in Liquid Suspension Dosage Form. Procedia Chem. 2014;13(0):119-127.

19. Grießmann K, Breitkreutz J, Schubert-Zsilavecz M, Abdel-Tawab M. Dosing accuracy of measuring devices provided with antibiotic oral suspensions. Paediatr Perinat Drug Ther. 2007;8(2):61-70. 
20. Yin HS, Mendelsohn AL, Wolf MS, Parker RM, Fierman A, Van Schaick L, Bazan IS, Kline MD, Dreyer BP. Parents' medication administration errors: Role of dosing instruments and health literacy. Arch Pediatr Adolesc Med 2010;164(2):181-186.

21. McMahon SR, Rimsza ME, Bay RC. Parents can dose liquid medication accurately. Pediatrics. 1997;100(3 Pt 1):330-333.

22. Scoutaris N, Alexander MR, Gellert PR, Roberts CJ. Inkjet printing as a novel medicine formulation technique. J Control Release. 2011;156(2):179-185.

23. Meléndez PA, Kane KM, Ashvar CS, Albrecht M, Smith PA. Thermal inkjet application in the preparation of oral dosage forms: Dispensing of prednisolone solutions and polymorphic characterization by solid-state spectroscopic techniques. Journal of pharmaceutical sciences. 2008;97(7):2619-2636.

24. Alomari M, Mohamed FH, Basit AW, Gaisford S. Personalised dosing: Printing a dose of one's own medicine. Int J Pharm. 2014;494(2):568-577.

25. Buanz AB, Saunders MH, Basit AW, Gaisford S. Preparation of personalized-dose salbutamol sulphate oral films with thermal ink-jet printing. Pharmaceutical research. 2011;28(10):23862392.

26. Boehm RD, Daniels J, Stafslien S, Nasir A, Lefebvre J, Narayan RJ. Polyglycolic acid microneedles modified with inkjet-deposited antifungal coatings. Biointerphases. 2015;10(1):011004.

27. Lee BK, Yun YH, Choi JS, Choi YC, Kim JD, Cho YW. Fabrication of drug-loaded polymer microparticles with arbitrary geometries using a piezoelectric inkjet printing system. Int J Pharm. 2012;427(2):305-310.

28. Lorber B, Hsiao WK, Hutchings IM, Martin KR. Adult rat retinal ganglion cells and glia can be printed by piezoelectric inkjet printing. Biofabrication. 2014;6(1):015001.

29. Uddin MJ, Scoutaris N, Klepetsanis P, Chowdhry B, Prausnitz MR, Douroumis D. Inkjet printing of transdermal microneedles for the delivery of anticancer agents. Int J Pharm. 2015;494(2):593-602.

30. Sandler N, Määttänen A, Ihalainen P, Kronberg L, Meierjohann A, Viitala T, Peltonen J. Inkjet printing of drug substances and use of porous substrates-towards individualized dosing. Journal of pharmaceutical sciences. 2011;100(8):3386-3395.

31. Chung P, Heller JA, Etemadi M, Ottoson PE, Liu JA, Rand L, Roy S. Rapid and low-cost prototyping of medical devices using 3D printed molds for liquid injection molding. Journal of visualized experiments : JoVE. 2014(88):e51745.

32. Dombroski CE, Balsdon ME, Froats $A$. The use of a low cost 3D scanning and printing tool in the manufacture of custom-made foot orthoses: a preliminary study. BMC research notes. 2014;7:443.

33. Water JJ, Bohr A, Boetker J, Aho J, Sandler N, Nielsen HM, Rantanen J. Three-Dimensional Printing of Drug-Eluting Implants: Preparation of an Antimicrobial Polylactide Feedstock Material. Journal of pharmaceutical sciences. 2015;104(3):1099-1107.

34. Boland T, Xu T, Damon B, Cui X. Application of inkjet printing to tissue engineering. Biotechnology journal. 2006;1(9):910-917.

35. Pati F, Shim J-H, Lee J-S, Cho D-W. 3D printing of cell-laden constructs for heterogeneous tissue regeneration. MFGLET. 2013;1(1):49-53.

36. Katstra WE, Palazzolo RD, Rowe CW, Giritlioglu B, Teung P, Cima MJ. Oral dosage forms fabricated by Three Dimensional Printing ${ }^{\text {TM }}$. J Control Release. 2000;66(1):1-9.

37. Yu D-G, Branford-White C, Yang Y-C, Zhu L-M, Welbeck EW, Yang X-L. A novel fast disintegrating tablet fabricated by three-dimensional printing. Drug Dev Ind Pharm. 2009;35(12):1530-1536.

38. Goyanes A, Buanz AB, Hatton GB, Gaisford S, Basit AW. 3D printing of modified-release aminosalicylate (4-ASA and 5-ASA) tablets. Eur J Pharm Biopharm. 2014;89:157-162. 
39. Melchels FPW, Feijen J, Grijpma DW. A review on stereolithography and its applications in biomedical engineering. Biomaterials. 2010;31(24):6121-6130.

40. Cooke MN, Fisher JP, Dean D, Rimnac C, Mikos AG. Use of stereolithography to manufacture critical-sized 3D biodegradable scaffolds for bone ingrowth. Journal of biomedical materials research Part B, Applied biomaterials. 2003;64(2):65-69.

41. Lan PX, Lee JW, Seol YJ, Cho DW. Development of 3D PPF/DEF scaffolds using microstereolithography and surface modification. Journal of materials science Materials in medicine. 2009;20(1):271-279.

42. Liska R, Schuster M, Inführ R, Turecek C, Fritscher C, Seidl B, Schmidt V, Kuna L, Haase A, Varga F, Lichtenegger $\mathrm{H}$, Stampfl J. Photopolymers for rapid prototyping. J Coat Technol Res. 2007;4(4):505-510.

43. Lu Y, Chen S. Projection printing of 3-dimensional tissue scaffolds. Methods in molecular biology (Clifton, NJ). 2012;868:289-302.

44. Melchels FP, Feijen J, Grijpma DW. A poly(D,L-lactide) resin for the preparation of tissue engineering scaffolds by stereolithography. Biomaterials. 2009;30(23-24):3801-3809.

45. McMains S. Layered manufacturing technologies. Commun ACM. 2005;48(6):50-56.

46. Chua CK, Leong KF, An J. 1 - Introduction to rapid prototyping of biomaterials. In: Narayan R, editor. Rapid Prototyping of Biomaterials: Woodhead Publishing; 2014. p. 1-15.

47. Suzuki M, Sawa T, Terada Y, Takahashi T, Aoyagi S. Fabrication of microneedles precisely imitating mosquito's proboscis by nanoscale tree dimensional laser lithography and its characterization. In.Transducers 2015; 2015. p. 121-124.

48. Skoog SA, Goering PL, Narayan RJ. Stereolithography in tissue engineering. Journal of materials science Materials in medicine. 2014;25(3):845-856.

49. Popov VK, Evseev AV, Ivanov AL, Roginski VV, Volozhin Al, Howdle SM. Laser stereolithography and supercritical fluid processing for custom-designed implant fabrication. Journal of materials science Materials in medicine. 2004;15(2):123-128.

50. Formlabs. Form 1+ high-resolution 3D printer. 6/11/2015. Available from: http://formlabs.com/products/form-1-plus/.

51. Tumbleston JR, Shirvanyants $D$, Ermoshkin N, Janusziewicz R, Johnson AR, Kelly D, Chen $K$, Pinschmidt R, Rolland JP, Ermoshkin A, Samulski ET, DeSimone JM. Continuous liquid interface production of 3D objects. Science. 2015;347(6228):1349-1352.

52. Aprecia. Zipdose ${ }^{\circledR}$ technology. 12/3/2015. Available from: https://aprecia.com/zipdoseplatform/zipdose-technology.php.

53. Seitz H, Rieder W, Irsen S, Leukers B, Tille C. Three-dimensional printing of porous ceramic scaffolds for bone tissue engineering. Journal of biomedical materials research Part $B$, Applied biomaterials. 2005;74B(2):782-788.

54. Huang $W$, Zheng $Q$, Sun W, Xu H, Yang X. Levofloxacin implants with predefined microstructure fabricated by three-dimensional printing technique. Int J Pharm. 2007;339(12):33-38.

55. Rowe CW, Katstra WE, Palazzolo RD, Giritlioglu B, Teung P, Cima MJ. Multimechanism oral dosage forms fabricated by three dimensional printing ${ }^{\mathrm{TM}}$. J Control Release. 2000;66(1):1117.

56. Fuh JYH, Lu L, Tan CC, Shen ZX, Chew S. Processing and characterising photo-sensitive polymer in the rapid prototyping process. J Mater Process Tech. 1999;89-90:211-217.

57. Sun Y, Soh S. Printing Tablets with Fully Customizable Release Profiles for Personalized Medicine. Advanced materials (Deerfield Beach, Fla). 2015;27(47):7847-7853.

58. Pyrce Lewis WE, Rowe CW, Cima MJ, Materna PA. System and method for uniaxial compression of an article, such as a three-dimensionally printed dosage form. In.: Patent $0198677 ; 2011$.

59. Yu DG, Yang XL, Huang WD, Liu J, Wang YG, Xu H. Tablets with material gradients fabricated by three-dimensional printing. Journal of pharmaceutical sciences. 2007;96(9):2446-2456. 
60. Wang CC, Tejwani Motwani MR, Roach WJ, Kay JL, Yoo J, Surprenant HL, Monkhouse DC, Pryor TJ. Development of near zero-order release dosage forms using three-dimensional printing (3-DP) technology. Drug Dev Ind Pharm. 2006;32(3):367-376.

61. Yu DG, Shen XX, Branford-White C, Zhu LM, White K, Yang XL. Novel oral fast-disintegrating drug delivery devices with predefined inner structure fabricated by Three-Dimensional Printing. The Journal of pharmacy and pharmacology. 2009;61(3):323-329.

62. Schmidt M, Pohle D, Rechtenwald T. Selective Laser Sintering of PEEK. CIRP Annals Manufacturing Technology. 2007;56(1):205-208.

63. Hunt JA, Callaghan JT, Sutcliffe CJ, Morgan RH, Halford B, Black RA. The design and production of $\mathrm{Co}-\mathrm{Cr}$ alloy implants with controlled surface topography by CAD-CAM method and their effects on osseointegration. Biomaterials. 2005;26(29):5890-5897.

64. Traini T, Mangano C, Sammons RL, Mangano F, Macchi A, Piattelli A. Direct laser metal sintering as a new approach to fabrication of an isoelastic functionally graded material for manufacture of porous titanium dental implants. Dent Mater. 2008;24(11):1525-1533.

65. Mangano C, Piattelli A, d'Avila S, lezzi G, Mangano F, Onuma T, Shibli JA. Early human bone response to laser metal sintering surface topography: a histologic report. J Oral Implantol. 2010;36(2):91-96.

66. Kang H, Long JP, Urbiel Goldner GD, Goldstein SA, Hollister SJ. A paradigm for the development and evaluation of novel implant topologies for bone fixation: implant design and fabrication. J Biomech. 2012;45(13):2241-2247.

67. Bae EJ, Kim HY, Kim WC, Kim JH. In vitro evaluation of the bond strength between various ceramics and cobalt-chromium alloy fabricated by selective laser sintering. J Adv Prosthodont. 2015;7(4):312-316.

68. Ding R, Wu Z, Qiu G, Wu G, Wang H, Su X, Yin B, Ma S, Qi B. Selective Laser Sinteringproduced porous titanium alloy scaffold for bone tissue engineering. Zhonghua Yi Xue Za Zhi. 2014;94(19):1499-1502.

69. Xie F, He X, Lu X, Cao S, Qu X. Preparation and properties of porous Ti-10Mo alloy by selective laser sintering. Mater Sci Eng C Mater Biol Appl. 2013;33(3):1085-1090.

70. Wendel B, Rietzel D, Kühnlein F, Feulner R, Hülder G, Schmachtenberg E. Additive Processing of Polymers. Macromol Mater Eng. 2008;293(10):799-809.

71. Van Hooreweder B, Moens D, Boonen R, Kruth J-P, Sas P. On the difference in material structure and fatigue properties of nylon specimens produced by injection molding and selective laser sintering. Polym Test. 2013;32(5):972-981.

72. Tan KH, Chua CK, Leong KF, Cheah CM, Cheang P, Abu Bakar MS, Cha SW. Scaffold development using selective laser sintering of polyetheretherketone-hydroxyapatite biocomposite blends. Biomaterials. 2003;24(18):3115-3123.

73. Williams JM, Adewunmi A, Schek RM, Flanagan CL, Krebsbach PH, Feinberg SE, Hollister SJ, Das $\mathrm{S}$. Bone tissue engineering using polycaprolactone scaffolds fabricated via selective laser sintering. Biomaterials. 2005;26(23):4817-4827.

74. Bertrand $\mathrm{P}$, Bayle F, Combe $\mathrm{C}$, Goeuriot $\mathrm{P}$, Smurov I. Ceramic components manufacturing by selective laser sintering. Appl Surf Sci. 2007;254(4):989-992.

75. Rombouts M, Kruth JP, Froyen L, Mercelis P. Fundamentals of Selective Laser Melting of alloyed steel powders. CIRP Annals - Manufacturing Technology. 2006;55(1):187-192.

76. Wong KV, Hernandez A. A Review of Additive Manufacturing. ISRN Mechanical Engineering. 2012;2012:10.

77. Goyanes A, Buanz AB, Basit AW, Gaisford S. Fused-filament 3D printing (3DP) for fabrication of tablets. Int J Pharm. 2014;476(1-2):88-92.

78. Skowyra J, Pietrzak K, Alhnan MA. Fabrication of extended-release patient-tailored prednisolone tablets via fused deposition modelling (FDM) 3D printing. European journal of pharmaceutical sciences : official journal of the European Federation for Pharmaceutical Sciences. 2015;68:11-17. 
79. Goyanes A, Martinez PR, Buanz A, Basit AW, Gaisford S. Effect of geometry on drug release from 3D printed tablets. Int J Pharm. 2015;494(2):657-663.

80. Pietrzak K, Isreb A, Alhnan MA. A flexible-dose dispenser for immediate and extended release 3D printed tablets. Eur J Pharm Biopharm. 2015;96:380-387.

81. Khaled SA, Burley JC, Alexander MR, Roberts CJ. Desktop 3D printing of controlled release pharmaceutical bilayer tablets. Int J Pharm. 2014;461(1-2):105-111.

82. Rattanakit $P$, Moulton SE, Santiago KS, Liawruangrath S, Wallace GG. Extrusion printed polymer structures: a facile and versatile approach to tailored drug delivery platforms. Int J Pharm. 2012;422(1-2):254-263.

83. Khaled SA, Burley JC, Alexander MR, Yang J, Roberts CJ. 3D printing of tablets containing multiple drugs with defined release profiles. Int J Pharm. 2015;494(2):643-650.

84. Khaled SA, Burley JC, Alexander MR, Yang J, Roberts CJ. 3D printing of five-in-one dose combination polypill with defined immediate and sustained release profiles. J Control Release. 2015;217:308-314.

85. Yu DG, Branford-White C, Ma ZH, Zhu LM, Li XY, Yang XL. Novel drug delivery devices for providing linear release profiles fabricated by 3DP. Int J Pharm. 2009;370(1-2):160-166.

86. Goyanes A, Wang J, Buanz A, Martinez-Pacheco R, Telford R, Gaisford S, Basit AW. 3D Printing of Medicines: Engineering Novel Oral Devices with Unique Design and Drug Release Characteristics. Mol Pharm. 2015;12(11):4077-4084.

87. Spence JD. Polypill: for Pollyanna*. International Journal of Stroke. 2008;3(2):92-97.

88. Lewanczuk R, Tobe SW. More medications, fewer pills: Combination medications for the treatment of hypertension. The Canadian Journal of Cardiology. 2007;23(7):573-576.

89. Charan J, Goyal JP, Saxena D. Effect of Pollypill on cardiovascular parameters: Systematic review and meta-analysis. Journal of Cardiovascular Disease Research. 2013;4(2):92-97.

90. Yu DG, Zhu L-M, Branford-White CJ, Yang XL. Three-dimensional printing in pharmaceutics: Promises and problems. Journal of pharmaceutical sciences. 2008;97(9):3666-3690.

91. Ursan ID, Chiu L, Pierce A. Three-dimensional drug printing: a structured review. J Am Pharm Assoc (2003). 2013;53(2):136-144.

92. pharmacy Uso. 3D printed animal-shaped tablets for children. 01/02/2016. Available from: https://www.ucl.ac.uk/pharmacy/pharmacy-news/animal-shaped-tablets.

93. Huang SH, Liu P, Mokasdar A, Hou L. Additive manufacturing and its societal impact: a literature review. Int J Adv Manuf Tech. 2013;67(5-8):1191-1203.

94. Pham DT, Gault RS. A comparison of rapid prototyping technologies. Int J Mach Tool Manu. 1998;38(10-11):1257-1287.

95. Gaylo CM, Pryor TJ, Fairweather JA, Weitzel DE. Apparatus, systems and methods for use in three-dimensional printing. In.: Google Patents; 2006.

96. Skelton J. Fused Deposition Modeling. 15/10/51. Available from: http://3dprint.blogspot.com/2008/02/fused-deposition-modelling.html.

97. Katstra WE, Palazzolo RD, Rowe CW, Giritlioglu B, Teung P, Cima MJ. Oral dosage forms fabricated by Three Dimensional Printing (TM). J Control Release. 2000;66(1):1-9.

98. Outterson K. Regulating Compounding Pharmacies after NECC. N Engl J Med. 2012;367(21):1969-1972.

99. Drues M. The Case of the New England Compounding Center. Healthcare packaging. 8/11/15. Available from: http://www.healthcarepackaging.com/case-new-englandcompounding-center.

100. Sun L. FDA finds widespread safety issues at compounding pharmacies. In. Washington Post: Health \& Science; 2013.

101. Colleen D, Lisa B, Matthew J, Farah T, James B, Gail D, Celeste L, MadaganKevin, MaidenTodd, Tracy Q, John S. 3D Printing of Medical Devices: When a Novel Technology Meets Traditional Legal Principles. reedsmith. 9/12/15. Available from: 
http://www.reedsmith.com/3D-Printing-of-Medical-Devices--When-a-Novel-TechnologyMeets-Traditional-Legal-Principles-09-09-2015/.

102. Drues M. Printing medical devices at home is just the beginning: Part II. 8/12/15. Available from: http://www.healthcarepackaging.com/trends-and-issues/3d-printingadditivemanufacturing/printing-medical-devices-home-just-beginning.

103. Sparrow N. FDA tackles opportunities, challenges of 3D-printed medical devices. In.Plastics today: Medicine; 2014.

104. Pollack S, Coburn J. FDA Goes 3-D. 30/11/15. Available from: http://blogs.fda.gov/fdavoice/index.php/tag/osel/.

105. FDA. Proposed Guidance Development and Focused Retrospective Review of Final Guidance. 15/12/15 Available from:

http://www.fda.gov/MedicalDevices/DeviceRegulationandGuidance/Overview/MDUFAlll/uc m321367.htm\#complete.

106. Drues M. 3D Printed Pill: Formulate, Download, and Print Your Own Medicine? AAPS webinars. 2/12/15. Available from:

https://www.aaps.org/eLearning/Webinars/2015/3D Printed Pill/.

107. Jacobson M. The Regulatory and Legal Implications of 3D Printing. In.MDT: Medical design technology; 2015.

108. FDA. Establishment registration and device listing for manufacturers and initial importers of devices. 15/12/15.

109. Zopf DA, Hollister SJ, Nelson ME, Ohye RG, Green GE. Bioresorbable Airway Splint Created with a Three-Dimensional Printer. N Engl J Med. 2013;368(21):2043-2045.

110. Chockalingam K, Jawahar N, Chandrasekhar U. Influence of layer thickness on mechanical properties in stereolithography. Rapid Prototyping J. 2006;12(2):106-113.

111. Gbureck U, Vorndran E, Muller FA, Barralet JE. Low temperature direct 3D printed bioceramics and biocomposites as drug release matrices. J Control Release. 2007;122(2):173-180.

112. Wu BM, Borland SW, Giordano RA, Cima LG, Sachs EM, Cima MJ. Solid free-form fabrication of drug delivery devices. J Control Release. 1996;40(1-2):77-87.

113. Wu W, Zheng $Q$, Guo X, Sun J, Liu Y. A programmed release multi-drug implant fabricated by three-dimensional printing technology for bone tuberculosis therapy. Biomedical materials (Bristol, England). 2009;4(6):065005.

114. Wang C-c, Yoo J, Bornancini E, Roach WJ, Motwani MR. Diffusion-controlled dosage form and method of fabrication including three dimensional printing. In.: US Patent 20,040,005,360; 2004.

115. Leong KF, Phua KKS, Chua CK, Du ZH, Teo KOM. Fabrication of porous polymeric matrix drug delivery devices using the selective laser sintering technique. P I Mech Eng $\mathrm{H}$. 2001;215(H2):191-201.

116. Low KH, Leong KF, Chua CK, Du ZH, Cheah CM. Characterization of SLS parts for drug delivery devices. Rapid Prototyping J. 2001;7(5):262-267.

117. Sandler N, Salmela I, Fallarero A, Rosling A, Khajeheian M, Kolakovic R, Genina N, Nyman J, Vuorela P. Towards fabrication of 3D printed medical devices to prevent biofilm formation. Int J Pharm. 2014;459(1-2):62-64.

118. Weisman JA, Nicholson JC, Tappa K, Jammalamadaka U, Wilson CG, Mills DK. Antibiotic and chemotherapeutic enhanced three-dimensional printer filaments and constructs for biomedical applications. International journal of nanomedicine. 2015;10:357-370.

119. Moulton SE, Wallace GG. 3-dimensional (3D) fabricated polymer based drug delivery systems. J Control Release. 2014;193:27-34.

120. Gbureck U, Vorndran E, Mueller FA, Barralet JE. Low temperature direct 3D printed bioceramics and biocomposites as drug release matrices. J Control Release.

2007;122(2):173-180. 
121. Wu C, Luo Y, Cuniberti G, Xiao Y, Gelinsky M. Three-dimensional printing of hierarchical and tough mesoporous bioactive glass scaffolds with a controllable pore architecture, excellent mechanical strength and mineralization ability. Acta Biomaterialia. 2011;7(6):2644-2650.

122. Jacob J, COYLE N, WEST TG, Monkhouse DC, Jain NB. Rapid Disperse Dosage Form Containing Levetiracetam. In.: Patent US20140271862 A1; 2014.

123. Wu W, Zheng $Q$, Guo $X$, Huang $W$. The controlled-releasing drug implant based on the three dimensional printing technology: Fabrication and properties of drug releasing in vivo. J Wuhan Univ Technol. 2009;24(6):977-981.

124. Maier A-K, Dezmirean L, Will J, Greil P. Three-dimensional printing of flash-setting calcium aluminate cement. J Mater Sci. 2011;46(9):2947-2954.

125. Cheah CM, Leong KF, Chua CK, Low KH, Quek HS. Characterization of microfeatures in selective laser sintered drug delivery devices. P I Mech Eng H. 2002;216(H6):369-383.

126. Leong KF, Chua CK, Gui WS, Verani. Building porous biopolymeric microstructures for controlled drug delivery devices using selective laser sintering. Int J Adv Manuf Tech. 2006;31(5-6):483-489.

127. Melocchi A, Parietti F, Loreti G, Maroni A, Gazzaniga A, Zema L. 3D printing by fused deposition modeling (FDM) of a swellable/erodible capsular device for oral pulsatile release of drugs. J Drug Deliv Sci Tec. 2015;30, Part B:360-367.

128. Masood SH. Application of fused deposition modelling in controlled drug delivery devices. Assembly Autom. 2007;27(3):215-221.

129. Petrak M, ROGERS L. Antimicrobial articles produced by additive manufacturing. In.: Google Patents; 2014.

130. Rowe CW, Katstra WE, Palazzolo RD, Giritlioglu B, Teung P, Cima MJ. Multimechanism oral dosage forms fabricated by three dimensional printing. J Control Release. 2000;66(1):11-17. 

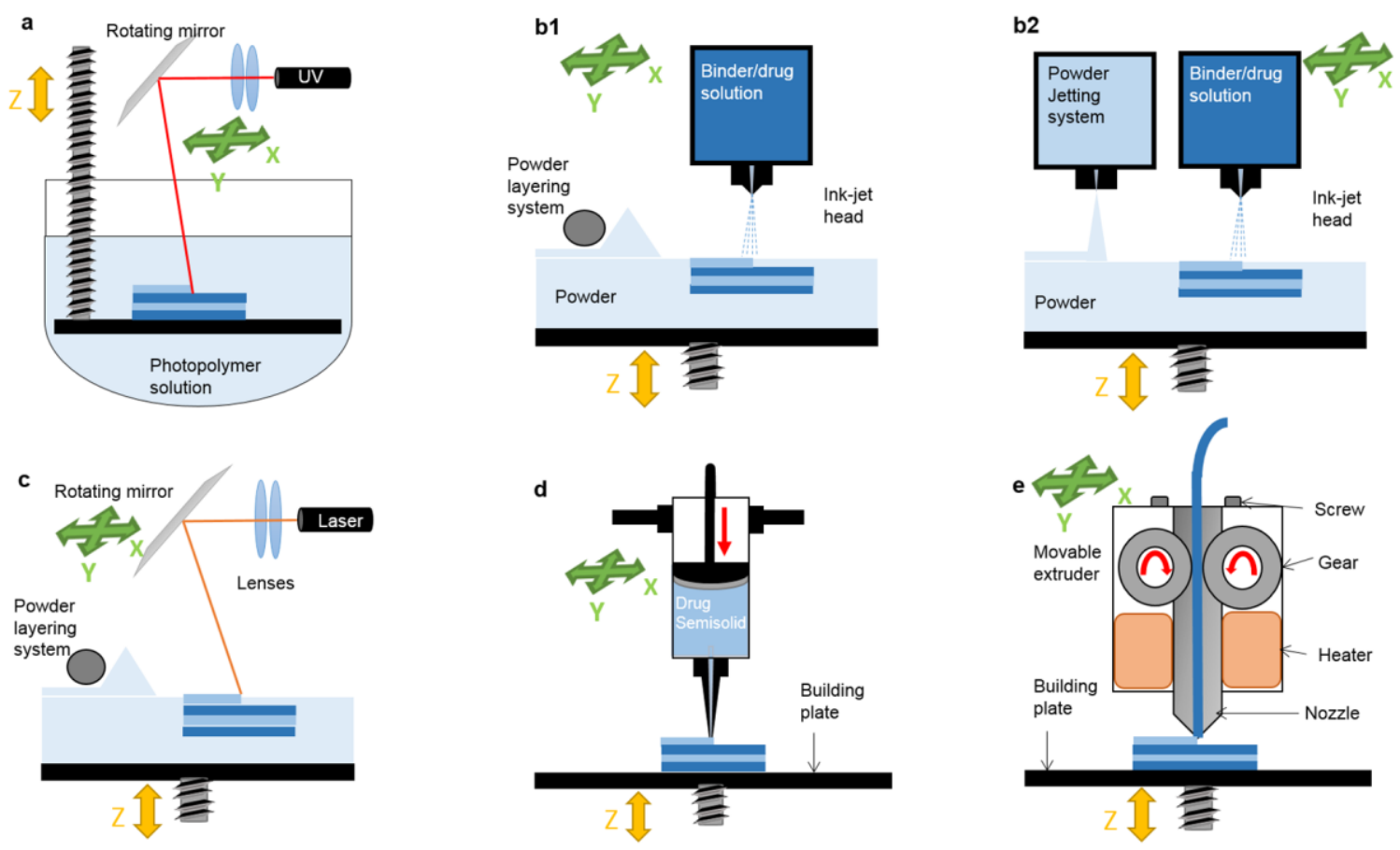

Fig. 1 Mechanism of various 3D printing technologies: (a) Stereolithographic (SLA), (b1-2) Powder bed and powder jetting, (c) Selective laser sintering (SLS), (d) Semi-solid extrusion (EXT) and (e) Fused deposition modelling (FDM). 


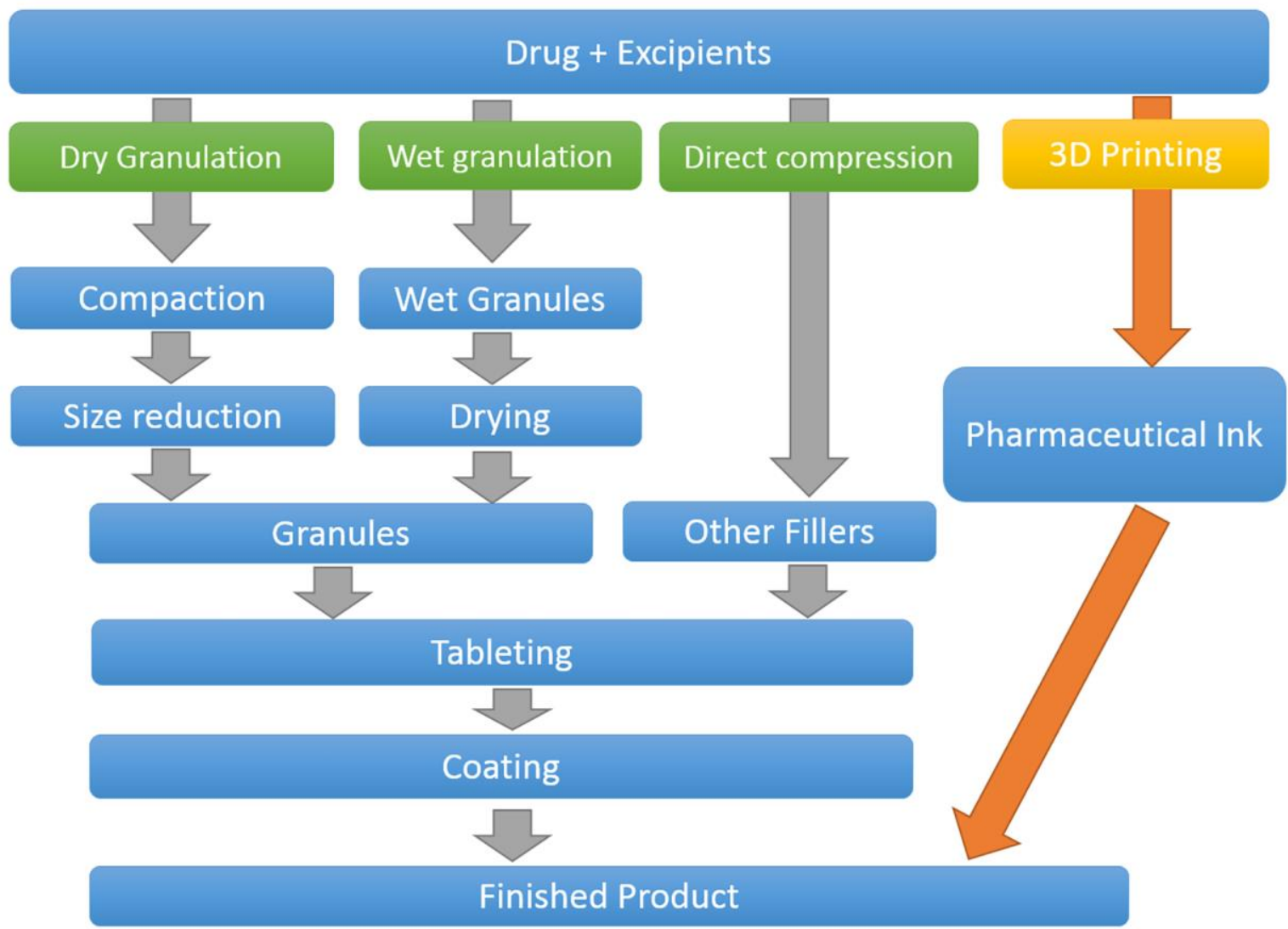

Fig. 2 Schematic diagram of different steps involved in tablet manufacturing. 3D printing can delay the last manufacturing step and bring it closer to patients. 

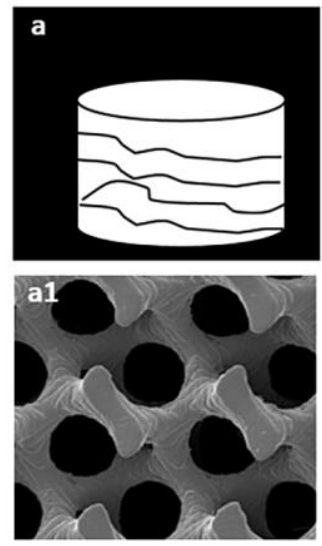
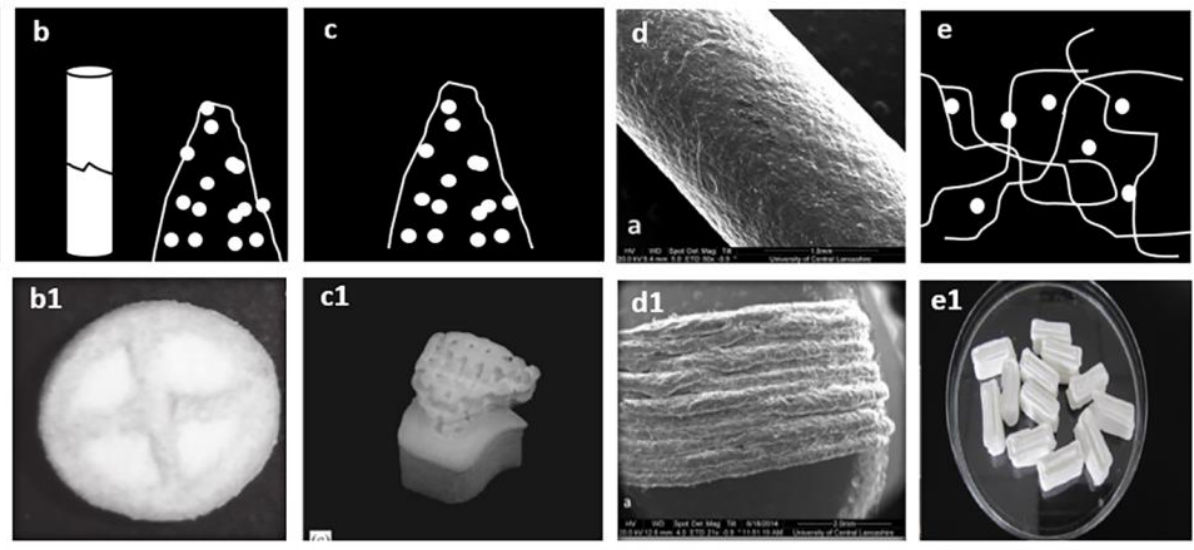

Fig. 3 Examples of starting material for 3D printing and their corresponding 3D printed products: (a) Oligomer solution and (a1) a scaffold printed using SLA (44) (b) Powder + binder solution and (b1) a tablet printed using PB (61), (c) Powdered polymer and (c1) a scaffold printed using SLS (73), (d) Filament and (d1) an extended release tablet printed using FDM (78), (e) Polymer solution + powder (semi-solid) and (e1) a controlled release bilayer tablet printed using EXT (81). (Awaiting permission). 


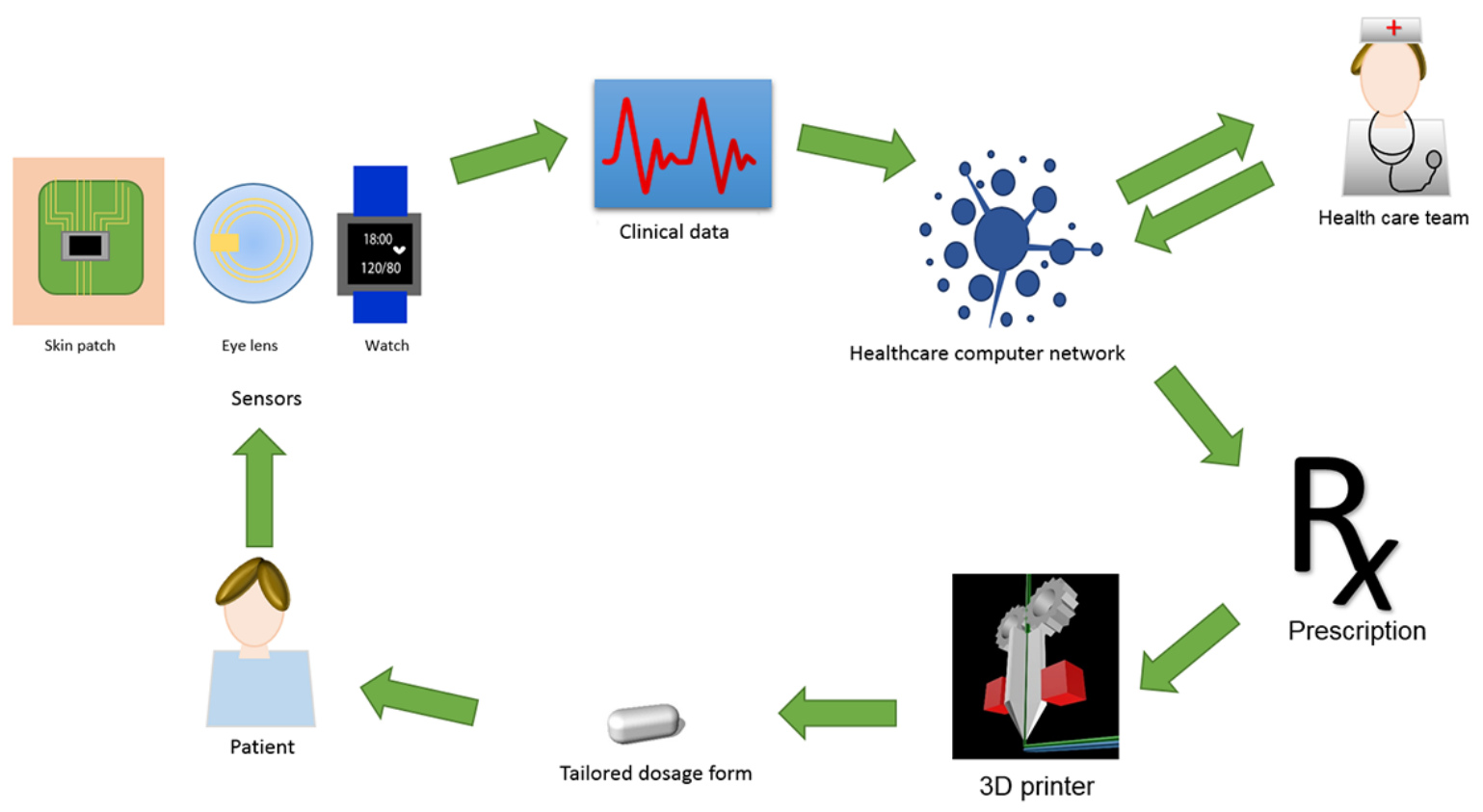

Fig. 4 Integration of 3D printing technologies within a proposed patient-centred healthcare system. Inline clinical data generated from sensors in patient's body feed into healthcare network. Healthcare staff can access the data and order an e-prescription of an individualised dosage form in response to patient's data. A 3D printer can locally fabricate the dose for the patient, hence providing an enhanced and seamless patient experience. 

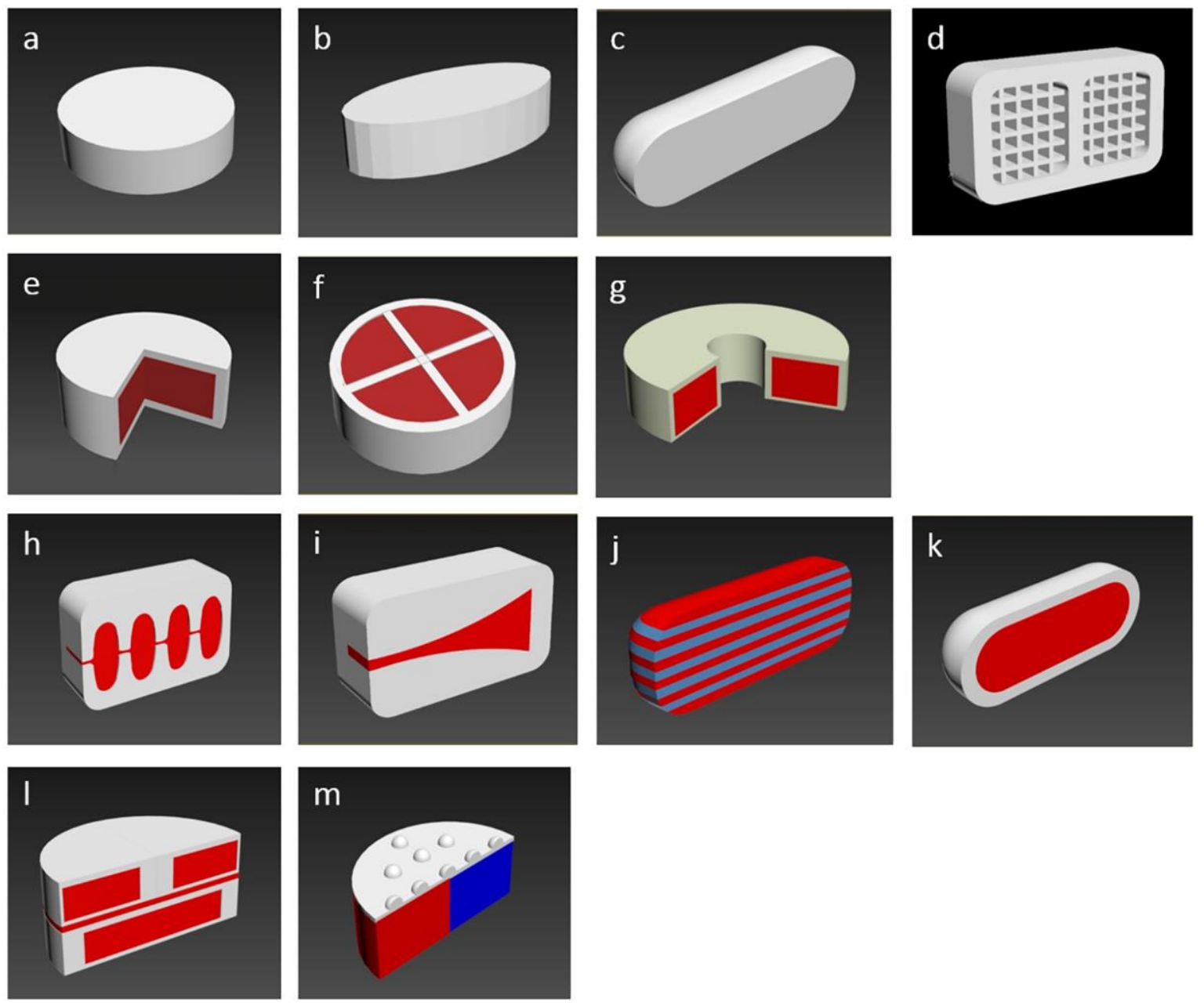

Fig. 5 Examples of different designs used to manufacture 3D printed tablets. Simplistic design of disc has been initially employed (a) (77). Oval shape (b) (78) and an easier to swallow caplet shape was possible to fabricate using FDM 3D printing (C) (80). FDM 3D printing allowed fabrication of partially hollow tablets (d) (77). PB 3D printing constructed shell-core structure by selective deposition of binder solution in the shell domains (e) (36) and by adding internal supporting walls, tablet's physical resistance can be improved (f) (61). PB 3D printing was also utilized to build doughnut shape tablets with linear drug release (g) (85). Pulsated drug release (h) and accelerating drug release (i) were achieved using casted gels in 3D printed containers (57). Multi-layer (j) and core-shell (k) caplets allowed simultaneous and sub sequential release of two actives (86). Polypills of 3 drugs (I) (83) or 5 different drugs (m) (84) with immediate and extended release patterns were EXT 3D printed. 
Table I Concept and minimum layer thickness of main stream 3D printing technologies

\begin{tabular}{llll}
\hline 3D Printing technology & Concept & Minimum & Reference(s) \\
& & layer thickness & $(110)$ \\
\hline $\begin{array}{l}\text { Stereolithography (SLA) } \\
\text { 3D printing }\end{array}$ & $\begin{array}{l}\text { Scanning a focused Ultraviolet (UV) laser over the } \\
\text { top of a photopolymerizable liquid in a layer by } \\
\text { layer fashion }\end{array}$ & $100 \mu \mathrm{m}$ & $(36,54,55$, \\
Powder Based (PB) 3D & $\begin{array}{l}\text { The ink (binders and APIs or binder solutions) is } \\
\text { sprinkled over a powder bed in two-dimensional } \\
\text { printing }\end{array}$ & $200 \mu \mathrm{m}$ & $59,61,85$, \\
& $\begin{array}{l}\text { fashion to make the final product in a layer by layer } \\
\text { fashion. }\end{array}$ & $111-114)$ \\
$\begin{array}{l}\text { Selective Laser Sintering } \\
\text { (SLS) 3D printing }\end{array}$ & $\begin{array}{l}\text { A laser beam sinters the powder and binds it in } \\
\text { layer-by-layer fashion. }\end{array}$ & $100 \mu \mathrm{m}$ & $(115,116)$ \\
$\begin{array}{l}\text { Fused deposition } \\
\text { modelling (FDM) 3D } \\
\text { printing }\end{array}$ & $\begin{array}{l}\text { Extruding a thermoplastic filament through high } \\
\text { temperature nozzle into semi-solid fused state } \\
\text { filament in layer by layer fashion. }\end{array}$ & $100 \mu \mathrm{m}$ & $(33,38,77$, \\
$\begin{array}{l}\text { Extrusion based (EXT) 3D } \\
\text { Printing }\end{array}$ & $\begin{array}{l}\text { Extruding semi-solids (e.g. homogeneous paste) } \\
\text { over moveable stage in layer by layer fashion into } \\
\text { a product }\end{array}$ & $800 \mu \mathrm{m}$ & $78,117-119)$ \\
&
\end{tabular}


Table II Summary of literature examples of 3D printed dosage form, intended aim, used active pharmaceutical ingredients (APIs) and excipients.

\begin{tabular}{|c|c|c|c|c|}
\hline $\begin{array}{l}\text { 3D Printing } \\
\text { technology }\end{array}$ & Type of dosage form & Intended aim & API/Excipients & Reference(s) \\
\hline \multirow[t]{14}{*}{$\begin{array}{l}\text { Powder based (PB) 3D } \\
\text { printing }\end{array}$} & Resorbable devices & Fabrication of novel dosage forms with controlled release profiles & $\begin{array}{l}\text { Methylene blue and alizarin yellow/ Polycaprolactone (PCL) and } \\
\text { polyethylene oxide (PEO) matrix materials }\end{array}$ & $(112)$ \\
\hline & Tablets & Fabrication of novel complex oral delayed-release tablets designs. & $\begin{array}{l}\text { Chlorpheniramine maleate and fluorescein disodium salt/ Eudragit E, } \\
\text { Eudragit RL in acetone or lactose, polyvinylpyrrolidone (PVP) Tween } 20 \\
\text { in deionised water }\end{array}$ & (36) \\
\hline & Multi-drug implants & Fabrication of multi-drug implants for bone tuberculosis & Isoniazid and rifampicin/ Poly(dl-lactic acid) (PDLLA) & (113) \\
\hline & $\begin{array}{l}\text { Microporous bioceramic } \\
\text { implants }\end{array}$ & $\begin{array}{l}\text { Fabrication of microporous implants containing antibiotics for bone } \\
\text { infections }\end{array}$ & $\begin{array}{l}\text { Vancomycin hydrochloride, ofloxacin and tetracycline hydrochloride/ } \\
\text { Microporous dicalcium phosphate dehydrate, dicalcium phosphate } \\
\text { anhydrous and hydroxyapatite. }\end{array}$ & $(120)$ \\
\hline & $\begin{array}{l}\text { Mesoporous bioactive glass } \\
\text { (MBG) }\end{array}$ & $\begin{array}{l}\text { Fabrication of mesoporous bioactive glass intended for bone } \\
\text { regeneration }\end{array}$ & Dexamethasone/ MBG powder and polyvinylalcohol (PVA) & (121) \\
\hline & Tablets & $\begin{array}{l}\text { Fabrication of fast disintegrating tablets with loose powder in their } \\
\text { central regions }\end{array}$ & $\begin{array}{l}\text { Acetaminophen and methylene blue/ lactose, PVP K30, mannitol, and } \\
\text { colloidal silicon dioxide }\end{array}$ & (37) \\
\hline & Tablets & Fabrication of controlled drug release tablets & $\begin{array}{l}\text { Acetaminophen/ Hydroxypropyl methylcellulose (HPMC), ethyl } \\
\text { cellulose, Eudragit RS, stearic acid and sodium lauryl sulphate }\end{array}$ & (59) \\
\hline & Tablets & $\begin{array}{l}\text { Fabrication of Four types of complex oral drug delivery tablets: (1) } \\
\text { Immediate-extended release, (2) Breakdown, (3) Enteric dual pulsatory, } \\
\text { (4) Dual pulsatory }\end{array}$ & $\begin{array}{l}\text { API: Chlorpheniramine maleate and diclofenac } \\
\text { Immediate-extended tablets - API/ Microcrystalline cellulose (MCC), } \\
\text { Eudragit E and Eudragit RL } \\
\text { Breakaway tablets - API/ MCC, lactose, Eudragit L100 and Kollidon SR } \\
\text { Enteric dual pulse tablets - API/ Eudragit L, MCC and spray-dried } \\
\text { lactose } \\
\text { Dual pulsatory tablets - API/ Eudragit E, Eudragit L, MCC and spray } \\
\text { dried lactose }\end{array}$ & (55) \\
\hline & cubic core-shell structures & $\begin{array}{l}\text { Development of zero order controlled release pseudoephedrine } \\
\text { hydrochloride formulations }\end{array}$ & $\begin{array}{l}\text { Pseudoephedrine hydrochloride/ Kollidon SR, HPMC and triethyl citrate } \\
\text { (TEC) }\end{array}$ & (60) \\
\hline & Implants & $\begin{array}{l}\text { Fabrication of an implant containing levoflocxacin intended for bacterial } \\
\text { infections }\end{array}$ & Levofloxacin/ poly-L-lactide (PLA) & (54) \\
\hline & $\begin{array}{l}\text { Multi-layer drug delivery } \\
\text { devices }\end{array}$ & $\begin{array}{l}\text { Design of a controlled drug release doughnut-shaped multi-layered drug } \\
\text { delivery devices }\end{array}$ & Acetaminophen/ HPMC and ethyl cellulose (EC) & (85) \\
\hline & Orodispersible dosage forms & Developing a rapidly oral dispersing dosage form of levetiracetam & $\begin{array}{l}\text { Levetiracetam/ MCC, glycerine, Tween 80, mannitol, povidone, } \\
\text { Sucralose: } 1-3 \text { Monoammonium glycyrrhizinate and colloidal silicon } \\
\text { dioxide }\end{array}$ & (122) \\
\hline & Implants & $\begin{array}{l}\text { Fabrication of drug implants with complicated architecture aimed at the } \\
\text { prophylaxis and treatment of bone diseases }\end{array}$ & Levofloxacin and rifampicine/ PLA & $(123)$ \\
\hline & Hydraulic cement systems & $\begin{array}{l}\text { Fabrication of a bone regenerating scaffold using calcium aluminate } \\
\text { cement }\end{array}$ & $\begin{array}{l}\text { Tricalcium aluminate and dodecacalcium heptaaluminate/ water- } \\
\text { glycerol }\end{array}$ & (124) \\
\hline $\begin{array}{l}\text { Extrusion based (EXT) } \\
\text { 3D printing }\end{array}$ & Polymeric structures & $\begin{array}{l}\text { Fabrication of novel drug delivery systems particularly intended for } \\
\text { chronic inflammatory disorders }\end{array}$ & $\begin{array}{l}\text { Dexamethasone-21-phosphate disodium/poly(lactic-co-glycolic acid) } \\
\text { (PLGA) and PVA }\end{array}$ & (82) \\
\hline
\end{tabular}




\begin{tabular}{|c|c|c|c|c|}
\hline & $\begin{array}{l}\text { Multi-active solid dosage forms } \\
\text { (polypill) }\end{array}$ & $\begin{array}{l}\text { Developing a cardiovascular treatment regime with one pill } \\
\text { incorporating } 5 \text { drugs in different immediate and extended release } \\
\text { compartments }\end{array}$ & $\begin{array}{l}\text { Aspirin, hydrochlorothiazide, atenolol, pravastatin sodium and } \\
\text { ramipril/ cellulose acetate, D-mannitol and polyethylene glycol (PEG } \\
6000) \text {. }\end{array}$ & (84) \\
\hline & Tablets & $\begin{array}{l}\text { Fabrication of a bilayer tablet for the treatment of respiratory tract } \\
\text { infections }\end{array}$ & $\begin{array}{l}\text { Guaifenesin/HPMC, poly(acrylic acid) (PAA), MCC and sodium starch } \\
\text { glycolate }\end{array}$ & (81) \\
\hline & $\begin{array}{l}\text { Tablets } \\
\text { (polypill) }\end{array}$ & $\begin{array}{l}\text { Development of a complex multi-compartment tablet incorporating } \\
\text { sustained release compartments for nifedipine and glipizide as well as } \\
\text { an osmotic pump for the drug captopril }\end{array}$ & Captopril, nifedipine and glipizide/ HPMC matrix & (83) \\
\hline \multirow{3}{*}{$\begin{array}{l}\text { Selective Laser } \\
\text { Sintering (SLS) 3D } \\
\text { printing }\end{array}$} & Shell core structure & Fabrication of controlled release drug delivery devices & Methylene blue dye/ Poly amide (PA) & $(125)$ \\
\hline & Cubic porous matrices & Fabrication of porous polymeric matrix drug delivery devices & Methylene blue dye/ Fine nylon powder & $(116)$ \\
\hline & $\begin{array}{l}\text { Porous biopolymeric } \\
\text { microstructures }\end{array}$ & Fabrication of porous polymeric disks as drug delivery systems & (N/A)/ PCL and PLA & (126) \\
\hline \multirow{10}{*}{$\begin{array}{l}\text { Fused Deposition } \\
\text { Modelling (FDM) 3D } \\
\text { printing }\end{array}$} & Tablets & $\begin{array}{l}\text { Feasibility of fabricating personalized-dose medicines or unit dosage } \\
\text { forms with controlled-release profiles }\end{array}$ & Fluorescein/ PVA & (77) \\
\hline & Tablets & Feasibility of using FDM to print tablets with different shapes & Acetaminophen/ PVA & (79) \\
\hline & Capsular devices & $\begin{array}{l}\text { Fabrication of novel swellable /erodible capsule shells able to achieve a } \\
\text { pulsatile release }\end{array}$ & Acetaminophen/ Hydroxypropyl cellulose (HPC) and PEG 1500 & $(127)$ \\
\hline & Tablets & Fabrication of modified-release drug loaded tablets & 5-Aminosalicylic acid (5-ASA) or 4-aminosalicylic acid (4-ASA)/ PVA & (38) \\
\hline & Tablets & $\begin{array}{l}\text { Feasibility of using FDM to print and control the dose of extended } \\
\text { release tablets }\end{array}$ & Prednisolone/ PVA & (78) \\
\hline & Tablets & $\begin{array}{l}\text { Development of a flexible dose tablet system able to print tablets with } \\
\text { immediate and/or extended drug release }\end{array}$ & Theophylline/Eudragit RL, RS, E and HPC & $(80)$ \\
\hline & Circular Discs & $\begin{array}{l}\text { Development of medical devices that are capable of preventing biofilm } \\
\text { formation }\end{array}$ & Nitrofurantoin/ PLA & (117) \\
\hline & Circular Discs & Feasibility of producing drug eluting implants & Nitrofurantoin/ PLA and hydroxyapatite nanoparticles & (33) \\
\hline & Reservoir-Matrix structures & Development of controlled drug delivery device matrices & Methylene blue dye/unspecified polymer & (128) \\
\hline & $\begin{array}{l}\text { Different medical constructs: } \\
\text { filaments, circular discs and } \\
\text { beads }\end{array}$ & $\begin{array}{l}\text { Development of dosage forms with sustained delivery of antibiotics and } \\
\text { chemotherapeutic drugs }\end{array}$ & Gentamicin or methotrexate/ PLA & (118) \\
\hline SLS or FDM 3D printing & Implants & $\begin{array}{l}\text { Use of different 3D printing techniques for the development of } \\
\text { antibiotic-eluting articles }\end{array}$ & Tobramycin, gentamicin, and vancomycin / PLA & (129) \\
\hline
\end{tabular}


Table III Summary of advantages and limitations of 3D printing technologies

\begin{tabular}{|c|c|c|c|}
\hline Technology & Advantages & Limitations & Reference(s) \\
\hline $\begin{array}{l}\text { Stereolithography (SLA) } \\
\text { 3D printing }\end{array}$ & $\begin{array}{l}\text { - Submicron sized objects and deci-micron sized } \\
\text { layers } \\
\text { - High accuracy and resolution; superior to all other } \\
\text { 3D printing techniques } \\
\text { - }\end{array}$ & $\begin{array}{l}\text { - } \text { Post-printing curing is required } \\
\text { - Carcinogenic risk of oligomers and limited to a } \\
\text { number of resins } \\
\text { - Costly equipment } \\
\text { - } \quad \text { Long printing time* }\end{array}$ & $(110)$ \\
\hline $\begin{array}{l}\text { Powder Based (PB) 3D } \\
\text { printing }\end{array}$ & $\begin{array}{l}\text { - } \text { Large choice of starting materials } \\
\text { - A room temperature process } \\
\text { - More porous matrix as compared to conventional } \\
\text { tableting with fast disintegrating time }\end{array}$ & $\begin{array}{l}\text { - } \text { Post-printing drying is required } \\
\text { - The friability and hardness are compromised for } \\
\text { fast disintegrating tablets } \\
\text { - Requires a specialized powder facility } \\
\text { - Significant wastage of powder }\end{array}$ & $\begin{array}{l}(54,59,61, \\
85,111-114, \\
130)\end{array}$ \\
\hline $\begin{array}{l}\text { Selective Laser Sintering } \\
\text { (SLS) 3D printing }\end{array}$ & $\begin{array}{l}\text { - Internal microstructure and porosity is highly } \\
\text { controllable and reproducible } \\
\text { - A single object can be built to contain variable } \\
\text { porosities and microstructures }\end{array}$ & $\begin{array}{l}\text { - } \text { Post-printing finishing process is are required } \\
\text { - } \quad \text { Limited speed for sinteration } \\
\text { - High energy input might degrade starting } \\
\text { material(s) }\end{array}$ & $(115,116)$ \\
\hline $\begin{array}{l}\text { Fused deposition } \\
\text { modelling (FDM) 3D } \\
\text { printing }\end{array}$ & $\begin{array}{l}\text { - Widely available and low cost printing units } \\
\text { - No post-printing processes are needed (unless a } \\
\text { raft is included in the structure) } \\
\text { - Mechanically resistant product with negligible } \\
\text { Friability }\end{array}$ & $\begin{array}{l}\text { - } \begin{array}{l}\text { High temperature process might degrade starting } \\
\text { material(s) }\end{array} \\
\text { - } \quad \text { Requires preparation of filaments in advance } \\
\text { - Confined to thermoplastic polymers }\end{array}$ & $\begin{array}{l}(33,38,77, \\
78,117-119)\end{array}$ \\
\hline
\end{tabular}


- High drug uniformity

\begin{tabular}{|c|c|c|}
\hline $\begin{array}{l}\text { Extrusion based (EXT) 3D } \\
\text { Printing }\end{array}$ & $\begin{array}{l}\text { - } \\
\text { - } \text { D room temperature process } \\
\text { - } \quad \text { Higher drug loading up to } 90 \%\end{array}$ & $\begin{array}{l}\text { - Low hardness and high friability } \\
\text { - Post-printing drying is required } \\
\text { - Resolution of printing is limited by nozzle size } \\
\text { - Difficult to control the flow of semi-solids through } \\
\text { the nozzle }\end{array}$ \\
\hline
\end{tabular}

* Continuous layer interface production (CLIP) technology can significantly shorten printing time (51) 
